\title{
Economías de aglomeración e innovación de empresas multinacionales localizadas en España
}

\author{
Enrique Claver-Cortés, Bartolomé Marco-Lajara ${ }^{1}$, Encarnación Manresa-Marhuenda, \\ Eduardo Sánchez-García
}

Universidad de Alicante, España

doi: $10.20420 /$ eni.2017.189

\begin{abstract}
Resumen
Dadas las actuales exigencias competitivas de un entorno cada día más global, la elección de una localización concreta por parte de las empresas multinacionales no sólo responde a la búsqueda de nuevos mercados sino también de conocimientos externos que favorezcan la innovación y su adaptación local. Ello explica que algunas de estas empresas elijan como emplazamiento lugares caracterizados por un mayor nivel de concentración empresarial, asumiendo un mayor riesgo de ser imitadas. Sin embargo, en última instancia, el acceso y el aprovechamiento del conocimiento externo depende de la habilidad de cada compañía para participar de las redes en las que se crea y comparte dicho conocimiento y para rentabilizarlo en forma de innovaciones de producto, proceso, prácticas organizativas y/o comerciales, mostrando los resultados alcanzados las diferencias existentes entre empresas foráneas y locales.
\end{abstract}

Palabras clave: localización, empresa multinacional, innovación, aglomeración, conocimiento, capacidad de absorción.

Clasificación JEL: D83, F23, L25, M16, R30.

Fuente de referencia: Claver-Cortés, E., Marco-Lajara, B., Manresa-Marhuenda, E., García-Lillo, F., \& Seva-Larrosa, P. (2017). Location decisions and agglomeration economies: domestic and foreign companies. Journal of Regional Research, 39 , 7-25.

\section{Introducción}

El enfoque seguido en la gestión del conocimiento y de la innovación por parte de las empresas multinacionales (MNEs) ha experimentado importantes transformaciones en los últimos tiempos, alterando los roles de la matriz y sus filiales, así como la dinámica de su relación.

Además de ser receptoras de la tecnología procedente de la matriz, se han consolidado otras funciones para las filiales vinculadas a la búsqueda de activos tecnológicos en el plano internacional y a la creación, sobre esas bases, de nuevas capacidades tecnológicas. La nueva dinámica en la relación matriz-filial ha sido impulsada por el aumento de la complejidad propia de los procesos de innovación, que requieren una combinación de conocimientos internos y externos.
Pero la colaboración con agentes de diferentes entornos por parte de las MNEs no es suficiente para poder acceder, captar e integrar el conocimiento externo. En particular, el conocimiento potencialmente útil para la innovación suele ser de naturaleza tácita, siendo difícil cumplir esta tarea en la distancia. En consecuencia, las decisiones sobre inversión directa en el exterior se plantean con una actualización de criterios que contempla nuevas funciones para las filiales.

$Y$ es a la elección de estos entornos a la que se ha prestado atención últimamente, ya que existen evidencias acerca de las externalidades de conocimiento que se generan gracias a la concentración de empresas en un mismo lugar. Por todo ello, recientemente han surgido diferentes trabajos tratando de explicar que el establecimiento de subsidiarias o filiales en mercados exteriores responde a la necesidad de

${ }^{1}$ Autor de correspondencia: bartolome.marco@ua.es 
acceder al conocimiento externo generado en ciertos entornos locales, de naturaleza tácita y potencialmente útil para la innovación.

No obstante, la idiosincrasia propia de cada contexto geográfico marca diferentes pautas de comportamiento, interacción y relación entre los agentes que en él se dan encuentro y que son fruto del desarrollo experimentado. En este caso, la MNE se sitúa en una posición de desventaja frente a las firmas locales, en el acceso a conocimiento externo, dado su mayor desconocimiento de las condiciones locales referentes a aspectos institucionales, culturales, etc.

Además, desde el enfoque de capacidades dinámicas se puede señalar que las condiciones externas que rodean a una empresa y, entre ellas, la elección de una localización próxima a otras empresas o co-localización no tiene por qué asegurar ni el acceso ni el aprovechamiento del conocimiento externo, que dependerá de la capacidad de absorción de cada firma.

Teniendo en cuenta estas reflexiones, el objetivo específico de este trabajo es contrastar si las economías de aglomeración influyen de forma distinta en la innovación de empresas nacionales y multinacionales, teniendo en cuanta el papel que juega la capacidad de absorción. Para ello, el artículo expone qué papel pueden jugar la localización en aglomeraciones y la capacidad de absorción en la innovación, diferenciando las condiciones de las empresas nacionales y las procedentes de otros países ${ }^{2}$. Los resultados confirman que el efecto de la aglomeración sobre la innovación depende de la naturaleza de la aglomeración, del tipo de innovación y de si la empresa es nacional o extranjera.

\section{Ventajas y desventajas de la aglomeración empresarial para las empresas multinacionales}

Diferentes trabajos muestran que las MNEs, en su decisión de localización, tienen preferencia por zonas o regiones caracterizadas por la concentración de la actividad económica o aglomeración al conseguir en ellas ciertas ventajas (Alcácer, Deszo, \& Zhao, 2013). Ejemplos de estas ventajas serían los menores costes y las mayores posibilidades de acceder a mano de obra específica y altamente cualificada, las derivadas de las negociaciones con gobiernos locales que conceden estímulos al establecimiento de actividades de $\mathrm{I}+\mathrm{D}$ en sus territorios, o el acceso a determinados recursos científico-tecnológicos gracias a la concentración de la actividad innovadora.

Desde el enfoque de la visión de la empresa basada en el conocimiento, la localización es una decisión de especial relevancia que ha de enfocarse a la búsqueda del conocimiento externo, de naturaleza tácita, que en ciertos contextos es fruto de la aglomeración y que puede constituirse como base de la ventaja competitiva.

Sin embargo, esta aglomeración también puede ser fuente de efectos negativos sobre los resultados empresariales, ya que la concentración de empresas genera lugares congestionados con una mayor competencia por los factores (terreno, trabajadores...) y que favorece una mayor exposición a la rivalidad competitiva.

Para tratar de esclarecer si el efecto neto de la localización en aglomeraciones es positivo o negativo debe tenerse en cuenta que éste no depende sólo del número de empresas que cohabitan en un entorno sino también de otras dimensiones (industrial, geográfica y temporal)

\footnotetext{
${ }^{2}$ En el texto se utilizan indistintamente los términos empresas multinacional, extranjera o foránea para referirse a aquellas empresas que son parte de otra con nacionalidad no española.
} 
de la aglomeración ${ }^{3}$, que establecen límites en términos del conocimiento que circula entre las empresas próximas.

En esta línea, algunos trabajos plantean que el "efecto del nivel de aglomeración" es función de la existencia y la magnitud de tres tipos de economías: las de urbanización, las de especialización y las de la intensidad del conocimiento características de cada lugar.

Las economías de urbanización (Jacobs, 1969) son aquellas derivadas de la concentración en una zona o región de empresas que desarrollan diversas actividades económicas. Esta concentración da lugar a una serie de ventajas tales como conexiones de transporte, dotación de infraestructuras, oferta de servicios, etc., que no dependen de la similitud entre las empresas que se co-localizan.

En este tipo de entornos se dan encuentro una pluralidad de realidades tecnológicas y comerciales, con la consiguiente multiplicidad de tipos de conocimiento, cuyo intercambio, complementariedad y combinación puede suponer un impulso a la creatividad y a la innovación. Sin embargo, la falta de conexión tecnológica y competitiva puede levantar barreras a la interacción entre empresas que aun no siendo rivales no hallan un punto de encuentro en el que cooperar. La existencia de una oferta amplia de servicios especializados y de agentes que actúen de conductores e intermediarios de estos encuentros debe recrear un ambiente en el que la cooperación entre empresas de distinta procedencia sea factible y permita generar nuevos conocimientos. Este tipo de entorno es el que se recrea en muchos Parques Científico-Tecnológicos en los que se intenta favorecer la innovación de las empresas multinacionales y nacionales que en ellos se localizan.

Las economías de especialización (Marshall, 1920), son aquellas derivadas de la especialización de la actividad económica en una industria dentro de una zona o región. Esta concentración espacial de empresas de la misma industria da lugar a ventajas tales como una mayor especialización de los trabajadores y de los abastecimientos, así como posibilidades de aprender unas empresas de otras. En este caso, el dominio de un lenguaje y una base de conocimientos comunes permiten que exista una mayor interacción entre firmas y, con ésta, una mayor probabilidad de generar nuevos conocimientos. Consecuentemente, este tipo de economías también favorece la innovación.

Finalmente, las economías de la intensidad del conocimiento (Knoben y otros, 2016) son características de zonas o regiones que, carentes de una especialización industrial, consiguen reunir a empresas, instituciones u otros agentes que destacan por su orientación al conocimiento y su potencial innovador, cuya convivencia genera un ambiente en el que se valora el conocimiento en sí mismo y se favorece la coordinación del esfuerzo colectivo y la transferencia de conocimiento. Esta mayor intensidad de conocimiento también favorece el acceso a conocimiento externo y, por ende, la innovación de las multinacionales.

\section{El papel de la capacidad de absorción}

Aunque pueden ser muchas las MNEs expuestas a condiciones idénticas del entorno, no todas son capaces de convertir los conocimientos externos en resultados con el mismo éxito, porque difieren en su capacidad para utilizar

\footnotetext{
${ }^{3}$ Por ejemplo, dos regiones distintas con el mismo número de empresas tendrán niveles de aglomeración diferentes, en función de la proximidad industrial de las empresas (dimensión industrial), por ejemplo. Incluso, aun siendo empresas de similar actividad industrial o sectorial, la aglomeración será distinta en función de la proximidad física entre las empresas (dimensión geográfica). Por último, no puede olvidarse si existe o no una historia de la aglomeración que haya generado un modelo de interacción y relación específico para las firmas que la ocupan (dimensión temporal).
} 
estas fuentes de conocimiento.

De hecho, a medida que aumentan las fuentes de conocimiento externo potencialmente útil al que la empresa tiene acceso, también aumentan las posibles combinaciones del mismo y, con ello, la complejidad de su gestión. En consecuencia, la incapacidad de la empresa para gestionar $\mathrm{y}$ aprovechar dicho conocimiento puede limitar sus posibilidades de innovación, siendo necesario destacar el papel de la capacidad de absorción -CA, en adelante(Cohen \& Levinthal, 1990). Esta capacidad directamente relacionada con la habilidad de la empresa para aprender, puede ser descrita a partir de sus tres dimensiones:

- Exploratoria, que permite explorar y tener receptividad ante el conocimiento procedente de fuera, localizando, identificando y valorando aquél que la firma considera valioso.

- Transformadora, que sirve para asimilar, comprender e internalizar el nuevo conocimiento, integrándolo con el stock de conocimiento interno ya existente, y que tras la combinación sufre una transformación.

- Explotadora, para poder aplicar el nuevo conocimiento, a partir de la base de conocimientos existente y de la inversión realizada en la generación y actualización de éste.

La pericia de estas filiales para innovar y, en última instancia, para sobrevivir, dependerá de su receptividad ante cambios en el entorno, de su propia habilidad para acumular este conocimiento y de su capacidad para rentabilizarlo. Por ello, se espera que un mayor desarrollo en las dimensiones exploratoria, transformadora y explotadora de la CA tenga un efecto positivo sobre la innovación de empresas MNEs.

\section{Diferencias entre empresas locales y foráneas}

A pesar de las ventajas señaladas de la localización en aglomeraciones, hay que tener en cuenta que la interacción que surge gracias a la proximidad a otras firmas no tiene por qué ser siempre provechosa. Este sería el caso de las MNEs que prefieren no localizarse junto a empresas domésticas porque perciben que la ganancia de conocimiento que pueden obtener es inferior al que pueden conseguir los rivales autóctonos.

Además, a diferencia del resto, el conocimiento potencialmente accesible para las filiales de MNEs puede proceder de su matriz, del entorno global o del entorno local.

Por otro lado, la proximidad geográfica entre agentes puede ser necesaria para promover procesos sociales de creación y transferencia de conocimiento, pero esta co-localización no es suficiente para generar la necesaria interacción entre agentes que produzca aprendizaje. En este sentido, las empresas locales se encuentran mejor posicionadas que las extranjeras para acceder y aprovechar el conocimiento externo local debido a su mayor nivel de integración en las redes locales. Es decir, sin las interacciones locales o la participación en dichas redes locales, las subsidiarias no pueden acceder y aprovechar los flujos informales de información, los recursos territoriales $\mathrm{y}$, en particular, el conocimiento externo potencialmente útil, normalmente de carácter tácito.

En conclusión, se puede afirmar que el aprendizaje inter-empresas en un entorno local necesita una interacción que no está asegurada por la proximidad de la localización de las instalaciones. Es necesario querer y poder participar en las redes locales de conocimiento, siendo mucho más probable que se den estas condiciones en el caso de las empresas locales, que disponen de menos alternativas y comparten 
más rasgos unas con otras. Teniendo en cuenta estas ideas, se puede pensar que la innovación de las empresas nacionales es más sensible a la aglomeración (en sus dimensiones de urbanización, especialización e intensidad del conocimiento) que la de las MNEs.

\section{El caso de las MNEs localizadas en España}

El contraste de las ideas expuestas se ha realizado sobre una muestra de 1610 empresas de sectores de alta y media-alta tecnología, que incluye 1371 empresas nacionales y 239 subsidiarias extranjeras situadas en España, que realizan $\mathrm{I}+\mathrm{D}$ en una sola Comunidad Autónoma (Claver y otros, 2017). Esta muestra y los datos utilizados proceden del Panel de Innovación Tecnológica (PITEC), que incluye la respuesta de empresas a la "Encuesta de innovación tecnológica en las empresas", y es elaborada por el Instituto Nacional de Estadística (INE) y la Fundación Española para la Ciencia y la Tecnología.

En el mapa se puede apreciar la distribución de la muestra por comunidades autónomas, correspondiendo la cifra entre paréntesis al número de filiales de MNEs.

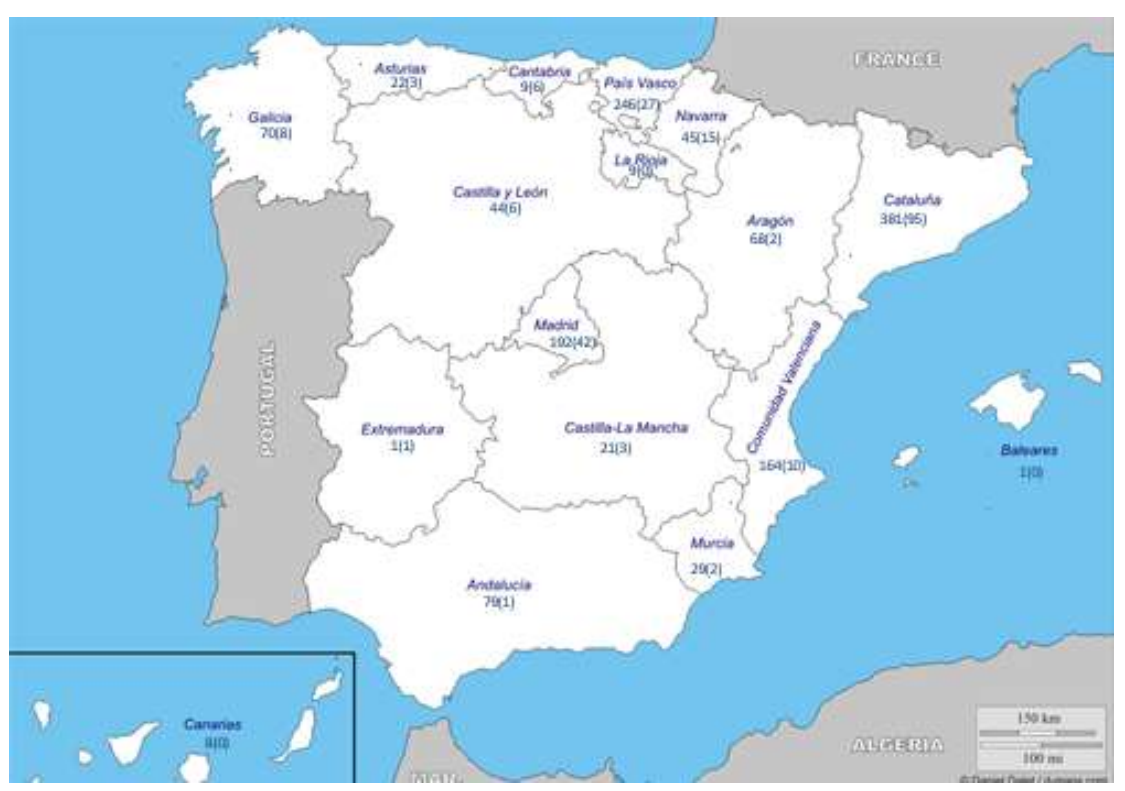

En el caso de filiales de MNEs los resultados obtenidos muestran que, de los tres tipos de economías de aglomeración consideradas, únicamente las economías de especialización tienen un efecto significativo sobre la innovación de producto/servicio, aunque de signo contrario al esperado. De modo que, cuanto mayor es la concentración de empresas similares en una zona menos innovadoras en productos/servicios son las filiales que eligen estas localizaciones.

Atendiendo al papel de la CA y a su influencia en la innovación, el efecto de la dimensión exploratoria, representativa de la apertura a nuevas ideas, se observa en las innovaciones tecnológicas - producto/servicio y proceso-, mientras que la dimensión transformadora, medida a través de la cualificación del factor humano, aumenta la probabilidad de innovar en comercialización. La influencia de la dimensión explotadora se deja sentir mínimamente en la innovación de tipo comercial.

En el caso de las empresas nacionales, la existencia de economías de urbanización favorece a aquellas empresas que apuestan por la innovación en procesos $\mathrm{y}$ en prácticas organizativas. Sin embargo, las innovaciones en comercialización son menos probables en las firmas con una mayor exposición a economías derivadas del conocimiento.

En cuanto a las economías de especialización, éstas tienen el efecto positivo esperado en la innovación tecnológica -producto/servicio y proceso-, mientras el signo se torna negativo en la innovación no tecnológica - prácticas organizativas y de comercialización-. En este asunto se puede entender que la localización en regiones con más agentes similares somete a las empresas a una mayor presión competitiva por el acceso a recursos (terrenos, trabajadores, financiación, etc.), siendo esta localización únicamente 
rentable para aquellas que pueden aprovechar en mayor medida el conocimiento que circula y que será más aplicable a innovaciones de tipo tecnológico. Por el contrario, para las empresas envueltas en actividades de innovación no tecnológica el valor del conocimiento externo potencialmente accesible no compensa el sobre coste del resto de factores:

Respecto a la CA, siendo distinta su magnitud y significatividad en cada tipo de innovación, tiene el efecto esperado. El efecto de la dimensión exploratoria se deja sentir en los cuatro tipos de innovación, el de la explotadora en procesos y prácticas organizativas -aunque la magnitud de éste es prácticamente inapreciabley el de la transformadora únicamente en innovaciones de producto/servicio.

\section{Conclusiones}

La primera de las tres conclusiones que se derivan del estudio es que para las empresas foráneas $\mathrm{y}$ domésticas existe un efecto diferencial sobre la innovación de las economías de aglomeración que, también varía dependiendo del tipo de aglomeración y de innovación. Las pruebas realizadas señalan que, en términos generales, en las empresas españolas las innovaciones de proceso $\mathrm{y}$ las no tecnológicas son las únicas que son sensibles a la localización en un parque y en zonas con una mayor concentración relativa de centros tecnológicos (economías de urbanización). Mientras, es la innovación en productos $\mathrm{y} / \mathrm{o}$ servicios de las empresas foráneas la única sensible a la mayor especialización sectorial relativa.

En segundo lugar, teniendo en cuenta los dos grupos de empresas, respecto a la influencia de la CA, se observa que en las innovaciones tecnológicas el elemento que ha mostrado mayor capacidad explicativa es la dimensión exploratoria de la CA. Mientras, la dimensión transformadora de la CA también aumenta la probabilidad de innovar en productos/servicios, en las empresas españolas, y en comercialización, en las empresas extranjeras. Por último, la dimensión explotadora de CA, es la que parece menos determinante de la innovación en las muestras estudiadas, ya que, a pesar de la significatividad de las relaciones, la magnitud de los efectos es mínima.

Finalmente, debe añadirse que las empresas mejor dotadas en términos de conocimiento dependen en menor medida de las ventajas que la localización en las aglomeraciones puede ofrecerles $\mathrm{y}$, en cambio, tienen una mayor necesidad de protección contra la exposición y la imitación de empresas rivales. Este argumento también estaría en línea con el de otros estudios que señalan que la co-localización favorece fundamentalmente a las empresas menos dotadas de recursos y conocimiento, perjudicando comparativamente a aquellas con un stock interno de conocimiento más desarrollado.

\section{Referencias}

Alcácer, J., Deszo, C., \& Zhao, M. (2013). Firm rivalry, knowledge accumulation, and MNE location choices. Journal of International Business Studies, 44(5), 504-520.

Claver-Cortés, E., Marco-Lajara, B., ManresaMarhuenda, E., García-Lillo, F., \& Seva-Larrosa, P. (2017). Location decisions and agglomeration economies: domestic and foreign companies. Journal of Regional Research, 39, 7-25.

Cohen, W., \& Levinthal, D. (1990). Absorptive capacity: a new perspective on learning and innovation. Administrative Science Quarterly, 35, 128-152.

Jacobs, J. (1969). The Economy of Cities. New York: Random House.

Knoben, J., Arikan, A.T., Oort, F., \& Raspe, O. (2016). Agglomeration and firm performance: One firm's medicine is another firm's poison. Environment and Planning, 48(1), 132-153.

Marshall, A. (1890/1920). Principles of Economics. London: MacMillan. 


\title{
Agglomeration economies and innovation of MNES located in Spain
}

\author{
Enrique Claver-Cortés, Bartolomé Marco-Lajara1, Encarnación Manresa-Marhuenda, \\ Eduardo Sánchez-García \\ Universidad de Alicante, España
}

\begin{abstract}
Given the current competitive demands of each time more global environment, the choice of a specific location by multinational companies not only responds to the search for new markets but also of external knowledge which encourages innovation and local adaptation. This explains the fact that some of these companies choose as location, places characterized by a higher level of business concentration despite the high risk of being imitated. Ultimately, however, the access to and the use of external knowledge depends on the ability of each company to participate in the networks where knowledge is created and shared; depending also on the capacity of the firm to apply it in innovation of products, processes, organizational and/or commercial practices. Results show the differences between foreign and local companies.
\end{abstract}

Keywords: Location choice, multinational enterprise, innovation, agglomeration, knowledge, absorptive capacity.

JEL classification: D83, F23, L25, M16, R30.

Reference source: Claver-Cortés, E., Marco-Lajara, B., Manresa-Marhuenda, E., García-Lillo, F., \& Seva-Larrosa, P. (2017). Location decisions and agglomeration economies: domestic and foreign companies. Journal of Regional Research, 39, 7-25.

\section{Introduction}

The approach followed in knowledge management and innovation by multinational enterprises (MNEs) has undergone major changes in recent times, altering the roles played by the parent company and its subsidiaries, as well as the dynamics of their relationship.

In addition to being recipients of the technology from the matrix, other functions have been consolidated for the subsidiaries related to the search for technological assets at the international level and to the establishment, on those bases, of new technological capacities. The new dynamic in the parent-subsidiary relationship, has been driven by the increase in the complexity of innovation processes, which require a combination of internal and external knowledge.
But the collaboration by MNEs with agents from different environments is not sufficient to be able to access, capture and integrate external knowledge. In particular, the potentially useful knowledge for innovation is often of tacit nature, being difficult to accomplish this task in the distance. As a result, decisions on foreign direct investment are raised with an update of criteria that includes new roles for the subsidiaries.

The choice of these environments is precisely a strategic decision that has received a lot of attention lately, as there are evidences about the externalities of knowledge that are generated due to the concentration of firms in one place. For all these reasons, various studies have emerged recently trying to explain that the establishment of subsidiaries or affiliates in foreign markets responds to the need to access the external knowledge generated in certain local

1Corresponding author: bartolome.marco@ua.es 
environments, of tacit nature and potentially useful for innovation.

Nevertheless, because each geographical context has its own idiosyncrasy, the interaction model prevailing in each region will be different, and their lack of familiarity with the specific conditions of the local environment (e.g. institutional and cultural aspects) places MNEs in a disadvantaged position with respect to local firms in terms of access to external knowledge.

Furthermore, it can also be stated from the dynamic capabilities approach that co-location neither necessarily ensures access to external knowledge nor its exploitation, which will ultimately depend on each firm's absorptive capacity.

Taking into account these ideas, the aim of this paper is to check if the effect of agglomeration economies on innovation is different for local firms and for Spanish subsidiaries of foreign MNEs, as well as to analyze the role played by absorptive capacity in this context. To achieve this proposal, the article explains the influence of location in agglomerations as well as the absorptive capacity, on innovation, differentiating the conditions surrounding domestic and foreign companies. Results confirm that the effect of agglomeration on innovation depends on the nature of the agglomeration, the type of innovation and whether the company is domestic or foreign.

\section{Advantages and disadvantages derived from the location in agglomerations for innovation in MNEs}

Different works show that MNEs have a preference for areas or regions characterized by agglomeration in their location decision because that type of location brings them certain advantages (Alcácer, Deszo \& Zhao, 2013). Examples of these advantages would be lower costs and better chances for the availability of specific and highly-qualified labor, those derived from the negotiations with local governments that provide incentives for the establishment of R\&D activities in their territories, or the access to a specific range of scientific-technological resources thanks to the concentration of innovative activity.

From the knowledge-based firm view, location comes to acquire special relevance for the MNE. The best location for the subsidiaries of an MNE will be the one which grants better chances of access to the external knowledge generated with agglomeration, specially knowledge of a tacit nature which constitutes the source of competitive advantage.

Nonetheless, this agglomeration may also result in negative effects on business results, since firm concentration generates congested places with a higher degree of competition for the various factors (land, workers...) that favors a greater exposure to competitors.

In an attempt to clarify if the effect that the agglomeration level has on innovation is positive or negative, it must be considered that agglomeration is an attribute of each location which depends not only on the number but also on the industrial, geographical, and time-related variety of the coexisting firms ${ }^{2}$. These characteristics additionally fix limits regarding the knowledge that circulates between neighboring enterprises.

Along these lines, several papers suggest that the "effect caused by the level of agglomeration"

\footnotetext{
${ }^{2}$ Two different regions with the same number of firms will have different levels of agglomeration according to the industrial proximity of enterprises (industrial dimension), for instance. Even if they are similar firms (belonging to the same industry and sector), agglomeration varies depending on the physical proximity between firms (geographical dimension). Finally, it is necessary to bear in mind the time dimension too, since the latter will determine if a history of agglomeration exists that has led to a specific interaction and relationship model for the firms occupying the region in question.
} 
largely depends on the existence, as well as on the importance acquired by the urbanization economies, specialization economies, and knowledge intensity economies that characterize each place.

Urbanization economies (Jacobs, 1969) are those resulting from the concentration of firms which develop various economic activities within a particular area or region. This concentration gives rise to a number of advantages or 'fixed effects' of location (e.g. transport connections, climate, time zone, or cultural capital) which do not directly depend on the co-location of related enterprises or institutions.

However, and most interestingly, environments like these, house a plurality of technological and commercial realities, with the resulting multiplicity of knowledge types, the exchange, complementariness, and combination of which may give a boost to innovation. The lack of technological and competitive connection is likely to raise barriers to interaction between firms, the existence of a wide range of specialized services and agents that can act as conductors and intermediaries for these encounters acquiring special relevance. This infrastructure must recreate an atmosphere where cooperation between enterprises -from very different origins and between which no direct rivalry exists - is feasible and permits to generate new knowledge. These kind of environments is typical of a Scientific and Technological Park, where innovation for domestic firms and MNEs located there is favored.

Specialization economies (Marshall, 1920) are the ones which derive from the specialization of economic activity in an industry within a specific area or region. Inside that location, firms will be able to enjoy advantages such as an increased specialization of workers or supplies. This spatial concentration of enterprises belonging to the same industry also generates externalities by the possibilities for companies to learn from one another. In this case, the mastery of a common language and knowledge base makes it possible to achieve a higher degree of interaction between firms, and as a result, a higher likelihood of generating new knowledge. Consequently, this kind of economics also favor innovation of MNEs.

Finally, knowledge intensity economies (Knoben and others, 2016) stem from the location close to knowledge-producing agents and/or firms, whose coexistence creates an environment where knowledge is valued, transferred, and generated. This higher knowledge intensity is the one which defines those areas or regions which, despite lacking in industrial specialization, manage to bring together agents characterized by their orientation towards knowledge and their innovative potential, creating an atmosphere that encourages the coordination of collective effort, and it is often driven by the role performed by certain local institutions. Thus, the existence of knowledge intensity economies also favors innovation of MNEs.

\section{The role played by absorptive capacity}

It can be stated in this respect that many MNEs are exposed to identical environmental conditions, but not all of them are able to turn external knowledge into results with the same level of success, because they differ in their ability to utilize these knowledge sources.

In fact, as firms gain access to more and more sources of potentially useful external knowledge, the possible combinations of that knowledge increase too and so does accordingly the complexity of its management. Therefore, if a firm is unable to manage and exploit such knowledge, that will most probably limit its possibilities to innovate, it being necessary to highlight the role of absorptive capacity - 
hereinafter AC- (Cohen \& Levinthal, 1990). This capacity directly associated with the firm's ability to learn, has three dimensions:

- Exploration, that allows to explore and show receptiveness before any knowledge coming from outside, locating, identifying, and assessing the one which is considered valuable.

- Transformation, that helps to assimilate and manage to understand and internalize new knowledge, integrating it into the already existing knowledge, which will suffer a transformation after the combination.

- Exploitation, with the aim to exploit and find the way to apply new knowledge, from the existing knowledge base and the investment made in its generation and updating.

The expertise of these subsidiaries to innovate and, ultimately, to survive, depends on their receptivity before changes in the environment, on their own skill to form part of external knowledge networks with other firms and institutions inside their own local environment, and on their ability to make the most of knowledge. Therefore, it is expected that a greater development achieved in the exploratory, transformative, and exploitative dimensions of $\mathrm{AC}$ will have a positive effect on innovation performed by MNEs.

\section{Differences between local and foreign firms}

In spite of advantages of location in agglomerations, it must bear in mind that the interaction which arises through the location near other firms, need not always be necessarily fruitful. This is the case of MNEs that prefer not to be located next to domestic firms because they have the impression that the possible gain of external knowledge that they might obtain is smaller than the one which those autochthonous rivals can achieve.
Moreover, the position of subsidiaries regarding knowledge management is peculiar because, unlike what happens with other types of firms, the external knowledge potentially accessible for them may come from its headquarter, the global environment or from the local environments of each one.

On the other hand, geographical proximity between agents becomes necessary to promote social learning processes by means of knowledge sharing and creation. This colocation does not suffice to generate the interaction between agents needed to produce that learning, though. Thus, local firms find themselves in a better position than foreign ones when it comes to accessing and exploiting local external knowledge due to their degree of integration into local networks. Without interactions and the existence of insertions in those local networks, the subsidiary will not be able to access and exploit non-formal information flows, territorial resources and, particularly, potentially useful external knowledge, normally of a tacit nature.

In other words, inter-firm learning within a local environment needs an interaction which is not always guaranteed by the proximity of facilities. There must be a desire and a capacity to participate in local knowledge networks, domestic companies being better positioned in this respect, since they have fewer alternatives and share more features with one another. Taking these ideas into account, it can be thought that innovation in local firms is more sensitive to agglomeration (in its urbanization, specialization, and knowledge intensity dimensions) than that undertaken in MNEs.

\section{The case of MNEs located in Spain}

The aforementioned ideas have been tested in a study with 1,371 domestic firms and 239 subsidiaries of foreign companies in Spain $-1,610$ firms in the total sample- belonging to 
high and medium-high technology sectors (Claver and others, 2017). The selected sample was obtained from the PITEC (Spanish abbreviation for Technological Innovation Panel) database, elaborated on the basis of the Survey about Innovation in Firms. This database has been prepared thanks to the collaboration between the National Statistics Institute (INE) and the Spanish Foundation for Science and Technology.

In the map it can be sawn the distribution for the population of firms by autonomous regions, alongside that of subsidiaries of foreign firms in Spain between brackets.

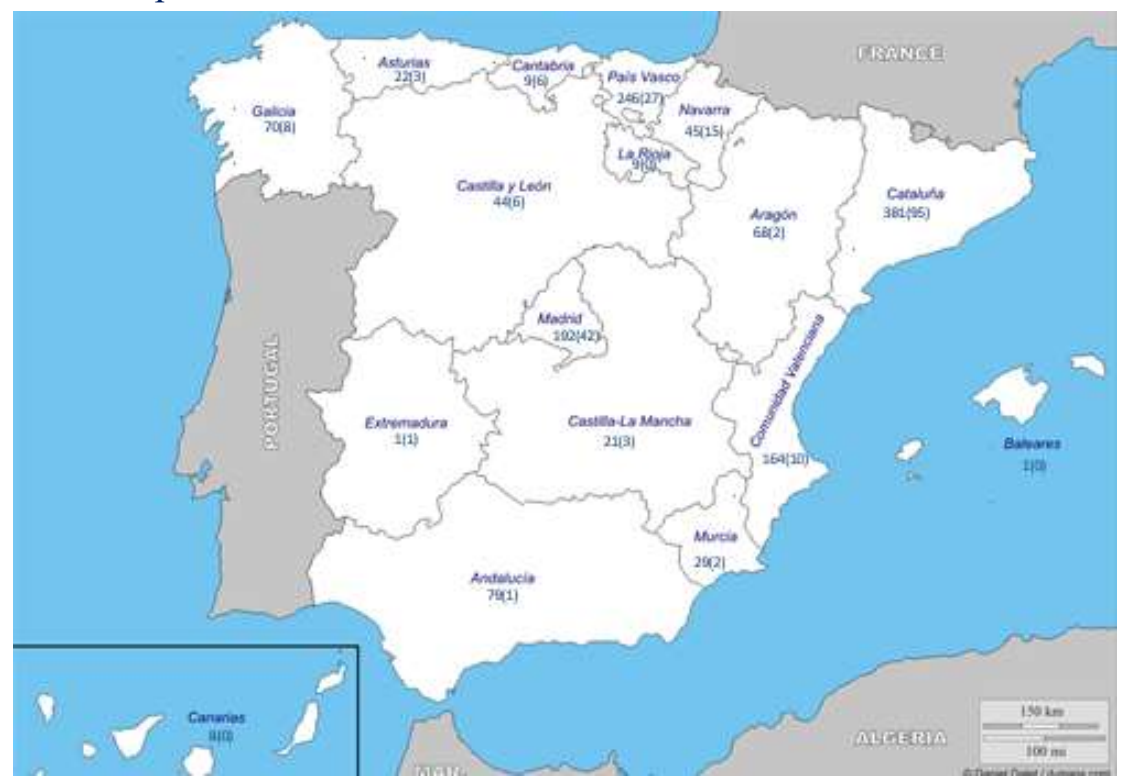

Of the three kinds of agglomeration economies that have been considered, the results achieved show that only specialization economies have a significant effect on product/service innovation of MNEs, though with a sign opposite to that expected. Therefore, as higher is the agglomeration of similar firms in the area, lower innovative in products/services are the subsidiaries of MNEs that choose this location.

Concerning the role of $\mathrm{AC}$ and its effect on innovation, the influence exerted by its exploratory dimension -representative of the opening to new ideas- can be observed in technological innovations, i.e. product/service and process, while the transformative dimension increases the chances to innovate in commercialization. The third dimension (the exploitative one) apparently influences innovation in commercial practices, although the magnitude of this effect is low.

In the case of domestic firms, the chances to innovate in processes and in organizational practices increase with urbanization economies. Nevertheless, innovation in commercialization becomes less likely when the knowledge economies are present.

Related to specialization economies, they have a positive effect in technological innovation - product/service and processes - and negative in non-technological innovation -organizational practices and commercialization practices. It can be understood in this respect that the location in regions with more similar agents puts firms under more competitive pressure for the access to resources (e.g. lands, workers, financing...), this location being only profitable for those firms able to take more advantage of the knowledge which is circulating and which will be more easily applied to innovations of a technological nature. On the contrary, for firms involved in non-technological innovation activities, the value of potentially accessible external knowledge does not compensate for the cost overrun in the rest of factors.

With regard to $\mathrm{AC}$, although it has a different magnitude and significance in each type of innovation, it has the expected effect. The effect of the exploratory dimension can be felt on all four sorts of innovation, that of the exploitative dimension arises in processes and organizational practices -even though its magnitude is almost negligible- and, finally, the effect of the 
transformative dimension can only be seen in product/service innovations.

\section{Conclusions}

Three are the main conclusions obtained with the study. The first is that the effect exerted by agglomeration economies on innovation does vary from foreign to domestic firms, and it changes depending on the type of agglomeration and innovation as well. The tests performed highlight that, in general, process and nontechnological innovations are the only ones showing sensitivity to urbanization economies when it comes to Spanish firms. Instead, only the innovation undertaken by foreign firms in products and/or services is sensitive to a higher relative sectorial specialization.

Secondly, taking both groups of firms into account, when it comes to $\mathrm{AC}$ influence, it is observed that the exploratory dimension of $\mathrm{AC}$ has proved to be the element showing a greater explanatory capacity in technological innovation. As for the transformative dimension of AC, it also increases the likelihood of innovating in products/services for Spanish enterprises, and in commercialization for foreign ones. Lastly, the exploitative dimension of AC is the one that seems to be less essential for innovation in the samples examined since, despite the significance of relationships, its effects are almost negligible.

Finally, it must be added that the best equipped enterprises in terms of knowledge depend to a lesser extent on the advantages that the location in agglomerations can bring them and, instead, have a greater need for protection against the exposure and imitation of rival firms. This argument would be in keeping with that of other studies according to which co-location essentially favors those firms which are less equipped with resources and knowledge, being comparatively detrimental to the ones which have a more developed internal knowledge stock.

\section{References}

Alcácer, J., Deszo, C., \& Zhao, M. (2013). Firm rivalry, knowledge accumulation, and MNE location choices. Journal of International Business Studies, 44(5), 504-520.

Claver-Cortés, E., Marco-Lajara, B., ManresaMarhuenda, E., García-Lillo, F., \& Seva-Larrosa, P. (2017). Location decisions and agglomeration economies: domestic and foreign companies. Journal of Regional Research, 39, 7-25.

Cohen, W., \& Levinthal, D. (1990). Absorptive capacity: a new perspective on learning and innovation. Administrative Science Quarterly, 35, 128-152.

Jacobs, J. (1969). The Economy of Cities. New York: Random House.

Knoben, J., Arikan, A.T., Oort, F., \& Raspe, O. (2016). Agglomeration and firm performance: One firm's medicine is another firm's poison. Environment and Planning, 48(1), 132-153.

Marshall, A. (1890/1920). Principles of Economics. London: MacMillan. 